\title{
EFFECT OF RHEOLOGICAL PROPERTIES OF MATERIALS ON THEIR TREATMENT WITH ULTRASONIC CAVITATION
}

\author{
VPLIV REOLOŠKIH LASTNOSTI MATERIALOV NA NJIHOVO \\ OBDELAVO Z ULTRAZVOČNO KAVITACIJO
}

\author{
Iryna Bernyk ${ }^{1}$, Oleksandr Luhovskyi ${ }^{1}$, Ivan Nazarenko ${ }^{2}$ \\ ${ }^{1}$ National Technical University (KPI), Department of Applied Hydro-Aeromechanics and Mechatronics, Institute of Mechanical Engineering, \\ Prosp. Peremohy 37, Solomyanskyi district, 03056 Kyiv, Ukraine \\ ${ }^{2}$ Kyiv National University of Construction and Architecture, Department of Machines and Equipment of Technological Processes, Faculty of \\ Automation and Information Technologies, Povitroflotsky Avenue 31, 03037, Kyiv, Ukraine \\ i_nazar@i.ua
}

Prejem rokopisa - received: 2017-02-10; sprejem za objavo - accepted for publication: 2018-02-02

doi:10.17222/mit.2017.021

\begin{abstract}
In the research, we proved that the optimum level of energy is the basis for an effective treatment of materials using ultrasonic cavitation. The key energy parameters are the pressure at the contact zone of the cavitator and material, and the speed of the contact zone movement. The main objectives of our work were to investigate the changes in the pressure components and determine their values considering the rheological parameters and the parameters of the dynamic material and cavitator. To achieve the objectives, we researched the elastic and dissipative components of rheological properties and determined their functions depending on the parameters of ultrasonic vibrations. The research methodology was based on the use of the fundamentals of the classical theory of acoustics. The mathematical description of the process was done using a model system including an acoustic apparatus and environment; this model was made by the authors. We calculated dissipation with the equations for environment motion considering two different laws of dissipation-factor changes; this was the requirement of the new model system. We proposed a new mathematical model; the researched system of the acoustic apparatus and the environment was considered as a whole. So, the elastic and dissipative parameters of the system were regulated among themselves. The selected mechanism of the regulation parameters was a system in resonance, achieved with a high-quality process of cavitation with a minimum energy consumption. We found the analytical dependence for determining the dynamic pressure on the environment with the acoustic apparatus. These dependencies provided the basis for assessing the influence of rheological properties on the treatment process using ultrasonic cavitation.
\end{abstract}

Keywords: material, rheological properties, ultrasonic cavitation, energy, pressure

V pričujoči raziskavi so avtorji dokazali, da je optimalni energijski nivo osnova za učinkovito obdelavo materialov z ultrazvočno kavitacijo. Ključna energijska parametra sta tlak v kontaktni coni kavitatorja in materiala, ter hitrost gibanja kontaktne cone. Glavni cilj raziskave je bil določiti njune vrednosti ob spreminjanju tlačnih komponent, $\mathrm{z}$ upoštevanjem reoloških parametrov in parametrov dinamike materiala in kavitatorja. Da bi dosegli cilje raziskave, so avtorji raziskovali elastične in disipacijske (izgubne) komponente reoloških lastnosti in določili njihove funkcijsko odvisne parametre ultrazvočnih vibracij. Raziskovalna metodologija je temeljila na uporabi temeljev klasične teorije akustike. Za matematični opis procesa so avtorji uporabili lastni modelni sistem akustični aparat - okolje. Izračunali so disipacijo $\mathrm{v}$ enačbah za gibanje okolja $\mathrm{z}$ dvema različnima zakonoma sprememb faktorjev disipacije; to je bila zahteva novega modelnega sistema. Avtorji so predlagali nov matematični model; raziskovani sistem akustični aparat - okolje, ki so ga obravnavali kot celoto. Tako elastični kot disipacijski parametri sistema so med seboj samoregulirani. Izbrani mehanizem parametrov reguliranja je bil sistem v resonanci. To so dosegli z visoko kvalitetnim procesom kavitacije ob najmanjši porabi energije. Dobili so analitično odvisnost za določitev dinamičnega tlaka na okolje z akustičnim aparatom. Ta odvisnost jim je služila za oceno vpliva reoloških lastnosti na proces obdelave z ultrazvočno kavitacijo.

Ključne besede: material, reološke lastnosti, ultrazvočna kavitacija, energija, tlak

\section{INTRODUCTION}

Today's technologies use cavitation as the major method for the materials treatment in various fields. ${ }^{1-12}$ The ultrasonic technology can intensify technological processes, increase the degree of raw-material utilization, change the material properties, create new substances and environments, ensure environmental and production safety. ${ }^{5}$ The existing research methods for the cavitation process are usually used separately for finding adequate machine constructions, ${ }^{13}$ they have to generate their vibrations with the resonance frequency, determined by various conditions. The technological aspect of the cavitation bubble process was also investigated.
Scientific works ${ }^{1,2}$ researched the processes of bubble formation and its oscillation, increasing the size with the next imploding bubbles; these works determined the factors such as the change in the external pressure on a separate bubble and the change in the pressure in its center, ${ }^{2}$ the sonoluminescence availability, ${ }^{8-10}$ the chemical effects of ultrasound, ${ }^{11,12}$ the temperature increase, ${ }^{2}$ the evaluation of a possible loss of the bubble spherical shape, ${ }^{2}$ the influence of viscosity, and the spatial and temporal dynamics of multiple bubbles. ${ }^{7}$ It was proved $^{7}$ that the threshold amplitude of the sound pressure needed to perform a cavitation process depends on many parameters; these include the static pressure, the sound frequency, the type of fluid, and the amount of dissolved 


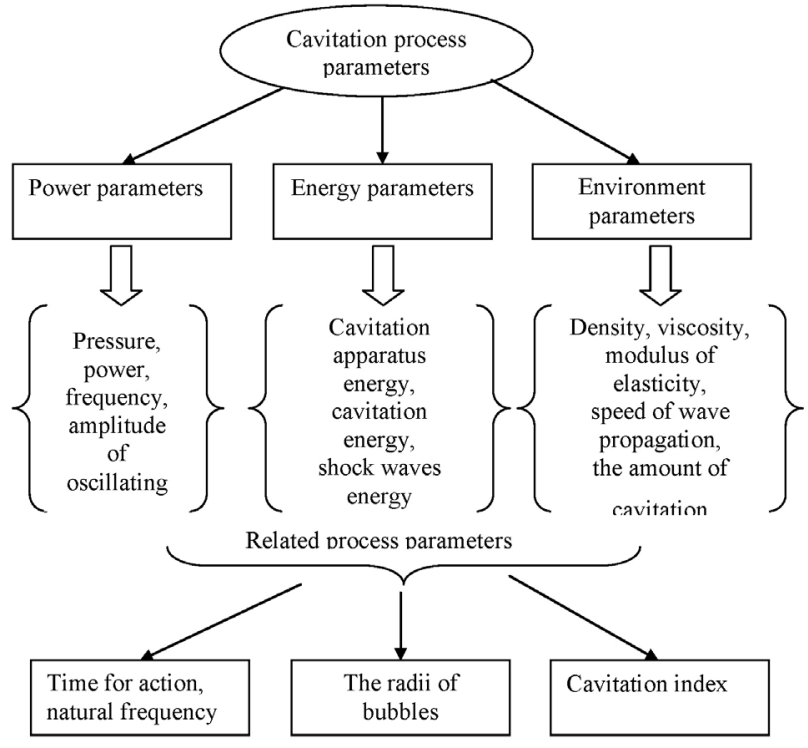

Figure 1: Parameters of a cavitation process for the treatment of a technological environment

gas and impurities. We should mention that a cavitation process is characterized by a number of parameters (Figure 1).

The above-mentioned studies made significant contributions to the understanding of the physics of a cavitation process, and the identification of the modes and parameters. However, there is the issue of the interaction of the cavitation machine and the treated material. How does the process of moving this system because of the energy transfer from the cavitator to the material due to the complex transfer of mass and heat in the current field, with a high cavitation transformation of the energy and shock waves take place? What model should describe the motion? The exact description of this process is too complicated, but it is obvious that this pressure is the key parameter of the evolution of gas and air bubbles in an acoustic field formed at the boundaries of the cavitator-environment system. Both the pressure and the energy used for the technological process of cavitation should be researched, obtaining the knowledge of the rheological properties of materials, and the acoustic parameters and characteristics of a cavitator. The research method was formed by assessing the impact of the rheological properties of the material on the resonance of the machine-environment system, considered for determining the parameters of the cavitation process as a single vibro-acoustical system.

\section{EXPERIMENTAL PART}

The methodological techniques for the research and for selecting the physical and mathematical models of the technological environments under the influence of cavitation require the knowledge of the rheological property changes such as elasticity, toughness and ductility. We researched the influence of rheological properties in the process of their treatment in terms of dispersed environments; their viscous and plastic properties were evaluated considering the laws of dynamic-viscositycoefficient change. The influence of the elastic and inertial properties of the technological environment in terms of cavitation treatment was considered when calculating the speed of wave propagation $c_{\mathrm{K}}$ in Equation (1): ${ }^{6}$

$$
c_{\mathrm{K}}=\sqrt{\frac{E}{\rho}}
$$

Where $E$ is the elastic modulus of the environment with the density $\rho$. The speed of the wave propagation determines the ratio of the elastic $(E)$ and mass $(\rho)$ characteristics of the environment, having a certain influence on the process of cavitation.

Equation (1) is mostly used for elastic environments; we should use the following equation for gas-saturated liquids: ${ }^{2}$

$$
c_{\mathrm{K}}=\sqrt{\rho \beta_{\mathrm{ac}}}
$$

where $\beta_{\mathrm{ac}}$ is the adiabatic compressibility. Comparing Equations (1) and (2), it should be noted that parameters $E$ and $\beta_{\text {ac }}$ are correlated as $\beta_{\text {ac }}=1 / E$.

The parameter $c_{\mathrm{K}}$ has a great influence on the process of cavitation. That is why it was researched in other scientific works. ${ }^{3,4}$ The speed of the sound in gas-liquid technological environments depends on the ratio between gas and liquid components; for example, water with gas bubbles has the range of change $c_{\mathrm{K}}$, which spans quite widely from $20 \mathrm{~m} / \mathrm{s}$ to $100 \mathrm{~m} / \mathrm{s}$. As we can see from source, ${ }^{4}$ numeric values of the cavitating liquid change in a narrow range: $c_{\mathrm{K}}=25 \ldots 30 \mathrm{~m} / \mathrm{s}$; reference ${ }^{3}$ includes the following numeric values: $c_{\mathrm{K}}=10 \ldots 12 \mathrm{~m} / \mathrm{s}$.

When choosing a dynamic model to determine the parameters of a cavitation process, the conditions of the interaction between the cavitation machine and technological environment were considered as well as the transferred and recorded energy of the contact zone in terms of their mutual oscillations. Under such conditions, the contact zone works for one oscillation period:

$$
A_{\mathrm{K}}=\int_{0}^{2 \pi / \omega} F_{K} \dot{x} \sin \alpha \cos \omega t \mathrm{~d} t
$$

Where $F_{\mathrm{k}}$ is the contact force with phase-shift angle $\alpha$ and the WRT amplitude of the contact zone; $\dot{x}$ is the speed of the contact-zone oscillation; $\omega$ is the oscillation frequency and $\mathrm{t}$ is the time.

It was decided that $F_{\mathrm{k}}=P_{\mathrm{k}} \cdot S$, where $P_{\mathrm{k}}$ is the pressure in the contact zone with an area of $S$.

The theory of the contact-pressure determination was based on the model of the cavitation machine-technological environment system; it was a discrete-continuum model following the laws of the changes in the frequency-independent and frequency-dependent dissipation coefficients. 
The equations of the acoustic-wave propagation for the frequency-independent model of the energy dissipation in the technological environment is the following:

$$
\frac{\partial^{2} u}{\partial z^{2}}=\frac{\rho}{E^{*}} \frac{\partial^{2} u}{\partial t^{2}}
$$

where $\rho$ is the environment density and $E^{*}$ is the complex module of elasticity.

The solution of Equation (4), according to the Fourier method, is presented as a complex wave function in Equation (5):

$$
u(z, t)=\sum_{n=-\infty}^{+\infty}\left(A_{1 n} e^{k_{n} z}+A_{2 n} e^{-k_{n} z}\right) e^{i n \omega t}
$$

Displacement $u$ is calculated with the product of two functions: one function is dependent on the argument $z(z)=A_{1 n} e^{k_{n} z}+A_{2 n} e^{-k_{n} z}$; the other function is only dependent on argument $T_{n}(t)=e^{i n \omega t}$. We have: $n-$ the number of harmonics, $k=\omega / \mathrm{c}, \omega-$ the oscillation frequency, c - the speed of the waves propagation in the environment, $i$ - the imaginary unit, $z$ - coordinate and $t$ - the time. In Equation (5), there are $A_{1 n}$ and $A_{2 n}$ - the constants determined from the boundary conditions.

Then, comparing the coefficients with the same harmonics after calculating the equations for constants $A_{1 n}$ and $A_{2 n}$, we have the following equation for calculating the environment pressure on the apparatus oscillation (the contact area):

$$
p(0, t)=\rho l A_{1} \omega^{2} \sqrt{\chi_{1 n}^{2}+\chi_{2 n}^{2}}
$$

where $A_{1}$ is the amplitude of the contact-zone oscillation, and $\chi_{1 n}$ and $\chi_{2 n}$ are the wave coefficients:

$$
\begin{aligned}
& \chi_{1 n}=\frac{\alpha_{n} \operatorname{sh} 2 \alpha_{n} l+\beta_{n} \sin 2 \beta_{n} l}{l\left(\alpha_{n}^{2}+\beta_{n}^{2}\right)\left(\operatorname{ch} 2 \alpha_{n} l+\cos 2 \beta_{n} l\right)} \\
& \chi_{2 n}=\frac{\alpha_{n} \sin 2 \beta_{n} l-\beta_{n} \operatorname{sh} 2 \alpha_{n} l}{l\left(\alpha_{n}^{2}+\beta_{n}^{2}\right)\left(\operatorname{ch} 2 \alpha_{n} l+\cos 2 \beta_{n} l\right)}
\end{aligned}
$$

The wave coefficients take into consideration line option 1 , and the acoustic wave extends along it. Coefficients $\alpha_{n}, \beta_{n}$ take into consideration the influence of dissipation on the shape and length of the wave of the n-th harmonic.

The wave equation for the frequency-dependent model of energy dissipation in the technological environment is the following:

$$
\frac{\partial^{2} u}{\partial t^{2}}=c \frac{\partial^{2} u}{\partial z^{2}}+\frac{4 \eta \partial}{3 \rho \partial t}\left(\frac{\partial^{2} u}{\partial z^{2}}\right)
$$

where $c$ is the speed of the wave propagation; and $\eta$ is the coefficient of viscosity.

The solution of Equation (9) is as follows:

$$
u(x)=A_{1} \cos k_{\mathrm{p}} x+A_{2} \sin k_{\mathrm{p}} x
$$

Where $k_{\mathrm{p}}$ is the complex constant of the wave propagation, calculated with the following equation:

$$
k_{\mathrm{p}}=k-i \psi=\frac{\omega}{c}-i\left(\frac{2 \eta \omega^{2}}{3 \rho c^{3}}\right)
$$

That is why the amplitude is calculated with the following equation:

$$
u=\left(A_{1} \cos k_{\mathrm{p}} x+A_{2} \sin k_{\mathrm{p}} x\right) \sin \omega t
$$

We have the equation to calculate the pressure in the contact zone:

$$
p=v_{0} \rho \omega \sqrt{\frac{(\sin k l \cos \psi l)^{2}-(\cos k l \operatorname{sh} \psi l)^{2}}{\left(k^{2}+\psi^{2}\right)\left[(\cos k l \operatorname{ch} \psi l)^{2}+(\sin k l \operatorname{sh} \psi l)^{2}\right]}}
$$

where $v_{0}$ is the speed of the contact-zone oscillation. We can calculate the amplitude of the ultrasonic pressure wave based on coefficient $\mathrm{k}$, resistance coefficient $\psi$ and the layer thickness for various technological environments due to this equation. The speed of wave propagation $c$ and density $\rho$ are very important parameters of Equation (12); the product of wave propagation $c$ and density $\rho$ is the wave impedance; its calculation depends on the rheological properties of the technological environment. Resistance coefficient $\psi$ is dependent on the viscosity; it also limits the amplitude of the system oscillation in the resonant mode. It influences the amplitude, formation and development of the cavitation field.

Taking into consideration the adopted approach, the coefficient of viscosity of technological environment $h$ was calculated with Equation (12):

$$
\eta=\frac{R_{a}}{v}
$$

where $R_{\mathrm{a}}$ is the active component of support; and $v$ is the speed of the system oscillation.

The input impedance of the oscillating system at its resonance frequency is $\mathrm{Z}=Z_{\mathrm{H}}+Z_{\mathrm{K}}$, so its equivalent resistance is equal to the load resistance $Z_{\mathrm{H}}$ and internal resistance of technological environment $Z_{C}$.

The calculation of the impedance of the cavitatorenvironment system $\mathrm{Z}$ was based on the measurement of

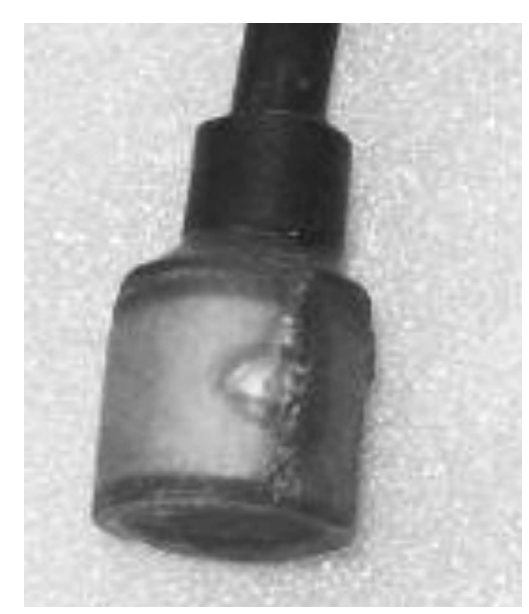

Figure 2: Measuring piezoceramic hydrophone 


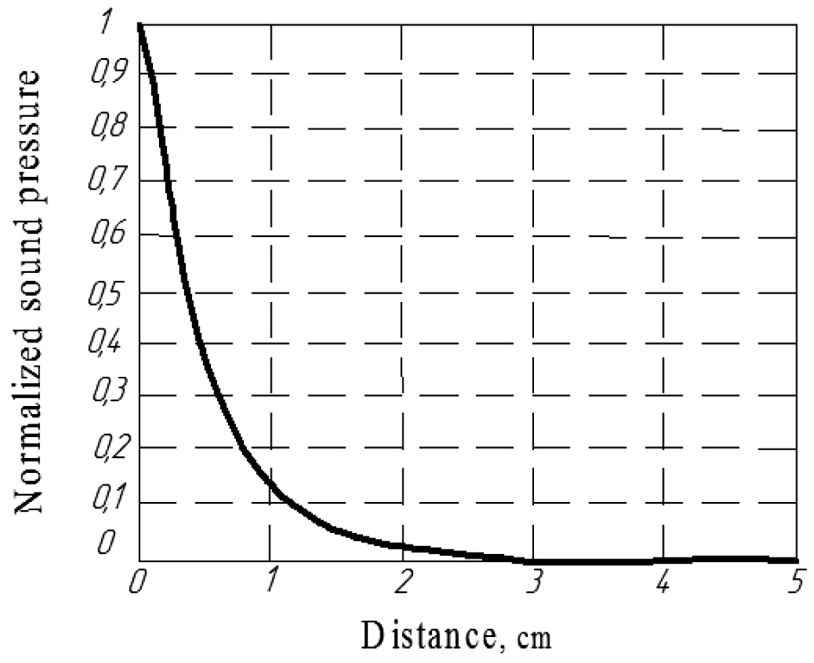

Figure 3: Dependence of the normalized sound pressure on the distance to the source of ultrasound

the sound pressure using piezoceramic hydrophones (Figure 2).

\section{RESULTS}

When the plates of the hydrophone piezo element are in the reception mode, the potential difference occurs; its value is proportional to the sound pressure. Taking into consideration the peak value of the sound pressure on the ultrasonic transducer axis:

$$
P(x)=P(0) \cdot e^{-\alpha x}
$$

we could draw a graph of normalized pressure $\bar{P}(x)$ from the coordinates of point measurements (Figure 3).

$$
\bar{P}(x)=\frac{P(x)}{P(0)}=e^{-\alpha x}
$$

\section{DISCUSSION}

It was observed that the most significant change in the sound pressure is at a distance of $10 \mathrm{~mm}$ from the radiating surface; its value is $20 \mathrm{~dB}$. The change in the shape of the sound field is no longer significant. Based on an overview of the impedance, ${ }^{6}$ we can conclude that the active part of the impedance represents the part of the energy spent for the formation of the cavitation process; the reactive component reflects the energy spent for the weight fluctuations of the technological environment. The viscosity action is essential for small values of the amplitudes at the initial stage of the bubble formation, when bubbles have small radii. The viscosity does not influence the bubbles with large initial radii. The reason for this is the fact that bubbles with small radii are constrained in their rise because of the viscous forces at the initial stage of the bubble formation. This conclusion is logical; to intensify the process of cavitation, the handling process should be used with the increasing acoustic pressure. Thus, both the viscosity coefficient of the environment and the elasticity coefficient are important parameters, influencing the formation of cavitation bubbles, their development and the final stage of the process - the compression and slamming.

\section{CONCLUSIONS}

The mathematical description of the motion of the system of cavitator-machining material is based on a model that was considered as a single, subdued wave process; the parameters of the mathematical model of the machine and the environment were coordinated among themselves.

The analytical dependence for calculating the contact pressure took into account the rheological properties of the material and adequately reflects the real conditions of the treatment with the ultrasonic cavitation.

The coefficients of elasticity and viscosity are important parameters, affecting the formation of cavitation bubbles, their development and the effectiveness of the final stage of the ultrasonic treatment of various technological materials.

\section{REFERENCES}

${ }^{1}$ M. Reiner, Rheology, Moscow, Nauka, 1965, 224

${ }^{2}$ L. Rozenberg, Cavitation area, Powerful ultrasonic fields, Nauka, Moscow, 1968, 223-265

${ }^{3}$ L. Davidenko, The characteristics of the medium and the acoustic field given in cavitation, Proceedings of the Odessa Polytechnic University, 29 (2008) 1, 245-250

${ }^{4}$ E. Rosina, Sound-Capillary Method for Determining the Velocity of Sound in a Cavitating Fluid, Acoustic Bulletin, 8 (2015) 4, 51-58

${ }^{5}$ O. Luhovskyi, N. Chukhraev, Ultrasonic cavitation in modern technologies, the Polydiene Center of the Kyiv University, Kyiv, 2007, 244

${ }^{6}$ I. Nazarenko, Applied tasks of theory of the oscillation systems, Kyiv, 2010, 440

${ }^{7}$ U. Parlitz, R. Mettin, S. Luther, I. Akhatov, M. Voss, W. Lauterborn, Spatio-temporal dynamics of acoustic cavitation bubble clouds, Phil. Trans. R. Soc. Lond. A, 357 (1999), 313-334

${ }^{8}$ R. J. Wood, J. Lee, M. J. Bussemake, A parametric review of sonochemistry: Control and augmentation of sonochemical activity in aqueous solutions, Ultrason. Sonochem., 38 (2017), 351-370

${ }^{9}$ K. S. Suslick, Sonoluminescence and Sonochemistry, Encyclopedia of Physical Science and Technology, 3rd ed., R. A. Meyers (ed.), Academic Press, Inc., San Diego, 2001, 22

${ }^{10}$ Kenneth S. Suslick, The Chemical Consequences of Cavitation, Sonoluminescence, http://icacommission.org>Proceedings/ICA2001 Rome/2_04.pdf, 12.04.2017

${ }^{11}$ S. K. Mishra, P. A. Deymier, K. Muralidharan, G. Frantziskonis, S. Pannala, S. Simunovic, Modeling the coupling of reaction kinetics and hydrodynamics in a collapsing cavity, Ultrason. Sonochem., 17 (2010), 258-265

${ }^{12}$ K. S. Suslick, G. J. Price, Applications of ultrasound to materials chemistry, Annu. Rev. Mater. Sci., 29 (1999), 295-326

${ }^{13}$ V. N. Khmelev, G. V. Leonov, R. V. Barsukov, S. N. Tsyganok, A. V. Shalunov, Ultrasonic multifunctional and specialized devices for the intensification of technological processes in industry, agriculture and household, Biysk, Publishing House of the Altai State Technical University, 2007, 400 